\title{
The Syllabus of the Regional Component of Professionally Motivational Education Developed for the Students Specializing in Tourism
}

\author{
Tatyana B. Lisitzina ${ }^{1}$, Vadim V. Nikonov ${ }^{1}$, Konstantin B. Ilkevich ${ }^{1}$, Tatyana G. Ilkevich ${ }^{1} \&$ Alfiya R. \\ Masalimova $^{2}$ \\ ${ }^{1}$ Gzhel State Art and Industry Institute, Ramensky region, Elektroizolyator, 67, Russian Federation \\ ${ }^{2}$ Kazan Federal University, Kazan, Kremlyovskaya Street, 18, Russian Federation \\ Correspondence: Tatyana B. Lisitzina, Ramensky region, Elektroizolyator, 67, 140155, Russian Federation. \\ E-mail: tat2254@yandex.ru
}

Received: September 23, 2014 Accepted: October 8, 2014 Online Published: December 20, 2014

doi:10.5539/ass.v11n2p284

URL: http://dx.doi.org/10.5539/ass.v11n2p284

\begin{abstract}
The development of types and forms of tourism in the regions of the Russian Federation is connected with the socio-cultural and economic transformations of the tourism market, which conditions continuous improvement of the system of professional tourism education at all levels. The expansion of tourism relations and tourism activities in the district, city, region defines the variety of professional tourism education. The article explains the syllabus of the regional component within general and special subjects, determining professional motivation of students majoring in Tourism in Gzhel region of developed folk arts and crafts. It also provides such forms of extracurricular work with the students to promote effective professionally motivational education in the forms of competitions, contests, touristic fairs, Month tourism, meetings with representatives of the actively developing touristic countries, probation in tourism, charity events for Gzhel schoolchildren-the excursions with animation program and others. In general, the results of the pilot work suggest the viability of the proposed syllabus of the regional component in professionally motivational training of the students majoring in Tourism in the region with the developed of folk arts and crafts.
\end{abstract}

Keywords: professionally motivational education, regional component, students specializing in "Tourism", Gzhel region

\section{Introduction}

\subsection{Background}

The organization of professional tourism education demands consideration of the interaction processes between educational globalization and fast technological tourism development (Shaidullina et al., 2014). The formation of the syllabus of professional tourism education requires constant monitoring of trends in tourism development. There is the need in systematic prognostic studies, which will help to take into account the changes in society, employment market and tourism sector and reflect these changes in the syllabus of tourism education (Ilkevich, 2011). The syllabus of professional tourism education should be aimed primarily at the positive changes in training future specialists of tourist areas to facilitate their employment and career growth.

Pedagogical understanding of the current educational situation in training for the tourism sector has brought to the search for new effective strategies for its transformation on the basis of professionally motivational education.

The problem of professionally motivational education of students majoring in Tourism in the region must be addressed primarily from the point of didactics factoring to the regional characteristics. An example of regional education is the Gzhel system of professional education aimed at meeting the need of industrial associations and enterprises in highly-qualified professionals of various levels among young people of the region; that is achieved through the integration of educational institutions, agencies, organizations and mass media (Lisitzina, 2007). The organizational unity of the education sphere of the region is simultaneously a condition, a form, a result of the organic integrity of education syllabus in the function of significant social experience adapted to be 
transmitted from generation to generation (Ilkevich \& Ilkevich, 2013).

In this context to school the students for the Tourism specialty in the region Gzhel of developed folk arts and crafts, it is necessary to provide a systematic approach to the problem of professionally motivational education revealing the nature, content and features of the profession at various stages of vocational education.

\subsection{The Features of the Gzhel Region}

Gzhel is the place of traditional folk arts and crafts. Here within the system of continuous professional education since the mid 70's the integration process of production, culture, art, science, and social infrastructure has been developing. Artistic aesthetic education and local youth upbringing has become the core of the regional educational system. The foundation of this system became primarily fostering and educational institutions in the region (starting from kindergarten) and enterprises (industrial and commercial, cultural institutions, health care, etc.). They were jointed into educational cultural research \& production center (UKNPTS) Gzhel. The main purpose of vocational training is to teach students to solve creative problems (Ilkevich \& Sukhodolova, 2011).

\subsection{Status of a Problem}

The major problems of educational theory and practice in this field appear unsatisfactory development of conceptual ideas and issues of professionally motivating Industrial Art Education.

Exploring motivation is a significant problem in modern pedagogy and psychology. In the works by $\mathrm{O}$. V. Vishtak (2003), E. P. Ilyin (2004) there are the discussions of the place and the role of professional motives in the structure of the individual motivational sphere. The motivational sphere of a person and peculiarities of its formation are revealed in the works by V. A. Popov and O. Y. Kondratyeva (1999), D. Dubovitskaya (2003) and others. To the motives of action and the mechanisms of their formation are devoted the papers by A. G. Bugrimenko (2006), Verbitsky A. A., N. A. Bakshaeva (1998). The studies by O. S. Gribenyuk, T. B. Gribenyuk (1998) and others indicate that the formation of professional motivation through educational activities is the most effective.

The analysis of the works of the abovementioned authors and many other publications in the topic showed that the issues related to the research of the professionally-motivating Industrial Art Education problem remain an understudied area of scientific knowledge and practical activities that has brought to development of the problem conceptual ideas.

\subsection{The Research Hypothesis}

The analysis of the theoretical studies and practical work in the aspect of the problem under study showed that the issues related to the regional characteristics of professionally- motivational education of students majoring in Tourism, nowadays remain understudied area of scientific knowledge and practices that allows us to formulate the hypothesis: professionally motivational education of college students majoring in Tourism in the region will be effective if there is the developed syllabus of the regional component of general professional and special subjects determining professional motivation of college students majoring in Tourism.

\section{Experimental}

\subsection{The Objectives of the Research}

The study followed the following objectives: 1) the choice of the experimental and control groups of students; 2) providing professionally- motivational training in the tourism sector with the students of the experimental group and traditional methods in the control group of students; 3 ) the comparison of the motivational sphere (motives, goals, emotions) of the students in the experimental and control groups in the process of tourism activities; 4) the analysis of the results of experiment, evaluation of the system effectiveness.

\subsection{Theoretical and Empirical Methods}

To test the hypothesis of the study a complex of various methods complementary to each other has been used:

- Theoretical-the analysis of literature, regulatory, legislative, instructional and tutorial, working papers and management and procedural materials of the investigated problem; studying and generalization of the innovative pedagogical experience, analysis, synthesis;

- Empirical-participant observation, ascertaining and forming pedagogical experiment, questionnaires, tests, interviews, conversations, the study of the results of academic and extracurricular students' activities, as well as the methods of mathematical statistics. 


\subsection{The Basis of the Research}

The basis of the research has become the state and public organizations: Karpovskiy Education Center, College of Gzhel State Art and Industry Institute, Institute for Postgraduate Training of the employees of the tourist and excursion companies, the tourism office of the Ramenkoe area, Ramenskii Education Center (circles on tourism and local history).

\subsection{The Stages of the Research}

The study was conducted in three stages:

At the first stage there was structured an experimental platform at the school tourist section within the Karpovskiy education center; there were curriculum, teaching and thematic plans of professionally motivational education developed and implemented in the educational process.

The second stage was intended to examine the programs of professionally-motivational education of the students majoring in Tourism in the region of folk arts and crafts; at the municipal level to implement a common educational space of tourism curricula and programs to ensure the unity of the processes of education and training, rehabilitation and career guidance of the students in the field of tourism and excursion activities.

At the third stage the programs were developed and tested; the results of the pedagogical experiment were summarized to analyze the effectiveness of the syllabus of the regional component of general and special subjects determining professional motivation of the college students majoring in Tourism; ordering and design of the study materials were carried out.

\subsection{Evaluation Criteria}

Evaluating the effectiveness of professionally motivational education of the students was carried out by means of the following criteria:

- The level of the motivational sphere of the student as an indicator of the psychological development degree of the future specialist;

- The level of professional mastery as an indicator of the quality of professional training.

\subsection{Proceedings and Description of the Experiment}

The ascertaining stage of the experiment included the diagnostic tests of the motivational sphere level of the students in the groups № 27 and № 47. For this purpose the two surveys has been chosen-the survey according to E. S. Chugunova method-the study of the motives for choosing a profession and the motives survey.

According to the obtained results it has been found out that the degree of manifestation of touristic activities motives and their ranking among the students of group number 27 differ in the least degree. The analysis of the average score values in special subjects has brought to the conclusion that the level of professional training of the students of the group № 27 largely corresponds to the level of professional training of the students from group № 47. The group № 27 has been selected experimental as the students showed the lowest levels of professional tourism motives and low progress in special subjects. The group № 47 was chosen as a control group according to the criteria of the least difference from the group№ 27.

During the formative phase of the experiment the students of the two training groups of 130 members each were involved: the group № 47-a control group (CG) and the group № 27-an experimental one (EG).

The pilot work has been carried out in accordance with the curriculum within the following disciplines study:

- The disciplines of the general education cycle: "Introduction to the profession", "Touristic service", "Animation activities";

- The disciplines of the general professional cycle: "Tourist Regional Studies of Russia";

- The disciplines of special series: "Technology and organization of tour operator and travel agency activities", "Organization of tourism", "Organization of domestic tourism", "Organization of ceramic production technology", "Museology", "Excursion activity", "the History of Gzhel Arts and Crafts".

The teaching process in the experimental groups included the full content of the regional component of general and special subjects that determines professional motivation of college students majoring in "Tourism".

\section{Results}

\subsection{The Regional Component of the Curriculum Subjects in the "Tourism" Specialty}

In the course of the general professional and special cycle subjects study, an integration program with the 
regional component was developed and implemented in the educational process. The main purpose of this program is the formation of professionally significant basic knowledge and development of personal motivation to absorb this knowledge.

The developed curricula disciplines of "Tourism" specialty are approximated to practice, implement the principles of professional motivation and are in conformity with the content of the students training for Tourism specialty in the region of folk arts and crafts. The syllabi of the disciplines "Tourism Regional Studies of Russia", "Technology and organization of tour operator and travel agency activity", the materials for professional and vocational testing have been approved by the Ministry of Education and Science of the Russian Federation and recommended for use in the specialty 100104 (2307) Tourism.

The regional component of general and special subjects determining professional motivation of college students majoring in Tourism is included in the curricula of many disciplines in the form of blocks, themes, modules devoted to Gzhel as the region of highly developed folk arts and crafts. Under teachers' guidance the students develop and test creative excursion projects and tourist routes of Gzhel. Of particular interest is the academic work in preparing and conducting the regional students Tourism Exhibition-Forum "Gzhel, tourism, sport, recreation" which is held annually in Gzhel. GGHPI The methodological guidelines for organization and conducting the exhibition and the forum have been reviewed by the Ministry of Education and Science of the Russian Federation and recommended for other educational institutions ACT implementing specialty 100104 (2307) Tourism.

Of particular importance for improving the students' professional motivation level in the process of study, as evidenced by the results of the submitted research is the special course "Innovation in the organization of the student tourism exhibition in the region", which takes into account regional peculiarities of Gzhel tourism industry, the purpose and objectives of which are to develop knowledge and skills of exhibition activities among the students majoring in "Tourism" in the region (the technology of preparation and conducting a tourism exhibition, using the means of tourist advertising in exhibitions, sales psychology of tourism products).

\subsection{Extracurricular Students' Work}

A crucial condition of the professional motivation formation is considerable in scope and diverse in form and content extracurricular students' work such as competitions, contests, tourism fairs, Tourism Month, students meeting with the representatives of the developing touristic countries, probation periods to educate in tourism and language practices abroad, charity events for Gzhel schoolchildren-excursions with animation program, assistance in organizing and conducting thematic holidays, participation in promotional tours, creative work in the Karpovskiy youth education center which boosts students' interest in the tourism industry in the country and the world, develop their responsibility for their performance.

Table 1. The dynamics of the students' participation in tourism activities

\begin{tabular}{|c|c|c|c|c|c|c|c|}
\hline \multirow{2}{*}{ № } & \multirow{2}{*}{ Name of the Event } & 2001 & 2002 & 2003 & 2004 & 2005 & \multirow[t]{2}{*}{ Total } \\
\hline & & \multicolumn{5}{|c|}{ Number of events / participating students } & \\
\hline 1 & Local & $4 / 360$ & $5 / 450$ & $6 / 620$ & $7 / 903$ & $8 / 1027$ & $30 / 3360$ \\
\hline 2 & District & $1 / 100$ & $2 / 198$ & $2 / 200$ & $3 / 356$ & $4 / 579$ & $12 / 1433$ \\
\hline 3 & Region & $2 / 80$ & $3 / 120$ & $4 / 234$ & $5 / 345$ & $6 / 457$ & $20 / 1236$ \\
\hline 4 & Russian & $1 / 57$ & $2 / 126$ & $3 / 210$ & $3 / 220$ & $4 / 362$ & $13 / 975$ \\
\hline 5 & International & $1 / 3$ & $1 / 3$ & $2 / 6$ & $3 / 10$ & $4 / 18$ & $11 / 40$ \\
\hline 6 & Hiking, excursion & $4 / 60$ & $8 / 210$ & $12 / 382$ & $18 / 561$ & $20 / 978$ & $62 / 2191$ \\
\hline 7 & $\begin{array}{l}\text { Seminars, conferences, Exhibitions, } \\
\text { tourism exhibitions }\end{array}$ & $1 / 56$ & $2 / 124$ & $4 / 300$ & $6 / 423$ & $10 / 1089$ & $23 / 1992$ \\
\hline 8 & Total events & 14 & 23 & 33 & 45 & 56 & 171 \\
\hline 9 & Number of participants & 716 & 1231 & 1952 & 2818 & 4510 & 11227 \\
\hline
\end{tabular}

The constituents of the basic professional syllabus are extracurricular activities. Taking it into consideration, we have developed a program of optional classes "Animation in the service of Gzhel tourists". The program aims at building students' competence in mastering animation techniques, designing a service program for the tourists arriving in Gzhel. 


\subsection{The Process and the Results of the Experiment}

At the first stage, the students' motivational sphere and professional skills were analyzed with the help of general maps. This helped to reveal their initial level. The comparative characteristics of the levels of the motivational sphere and professional mastery showed that the students of the experimental and control groups had identical average level of the professional factor of the motivational sphere.

The number of students having the first level of the motivational sphere development grouped into: the experimental group- $18 \%$, in the control group- $13 \%$; the second level: in the experimental group- $39 \%$ in the control group- $35 \%$; third level- $24 \%$ and $28 \%$.

The number of students having the first level of professional skills development grouped: in the experimental group- $15 \%$; in the control group- $10 \%$; the second level: in the experimental group-39\% in the control group- $32 \%$; the third level- $21 \%$ and $26 \%$ respectively. The number of students who had the 5 th and 6 th levels made no more than $10 \%$ of both groups.

Thus, more than half of the students in the experimental group- $63 \%$ in the beginning of the experiment were assigned to the first and second levels of the professional component of tourist motivation. In the control group the number of such students was somewhat lesser-50\%. The professional knowledge for them implies a means to achieve personal well-being. In the process of forming experiment $2 \%$ out of $20 \%$ of the students in the experimental group, with the initial level of professional skills development, at the end of the school year were assigned to the second level. Among $43 \%$ of the students with 2 nd level of motivation, $17 \%$ has revealed its development. The levels of motivation 5 and 6 were observed among $17 \%$ of the students, instead of $10 \%$-at the beginning of the experiment. The positive dynamics of the motivational sphere of tourism skills was observed among 54\% of the students in the experimental group. Negative shift of motives has not been recorded.

A similar control of the motivational sphere and touristic skills was carried out among the control group of the students. Here, the positive changes were observed among a small number of students. A significant proportion of students showed negative dynamics in the motivational sphere. Only one of four students in the control group with the first level of development of motivation at the end of the school year was allocated to Level 2. Positive changes in the levels of the motivational tourist sphere and skill was observed in $19 \%$ of the students trained in the control group. The negative shift in the motivational sphere of tourist and skill was recorded among $26 \%$ of the students.
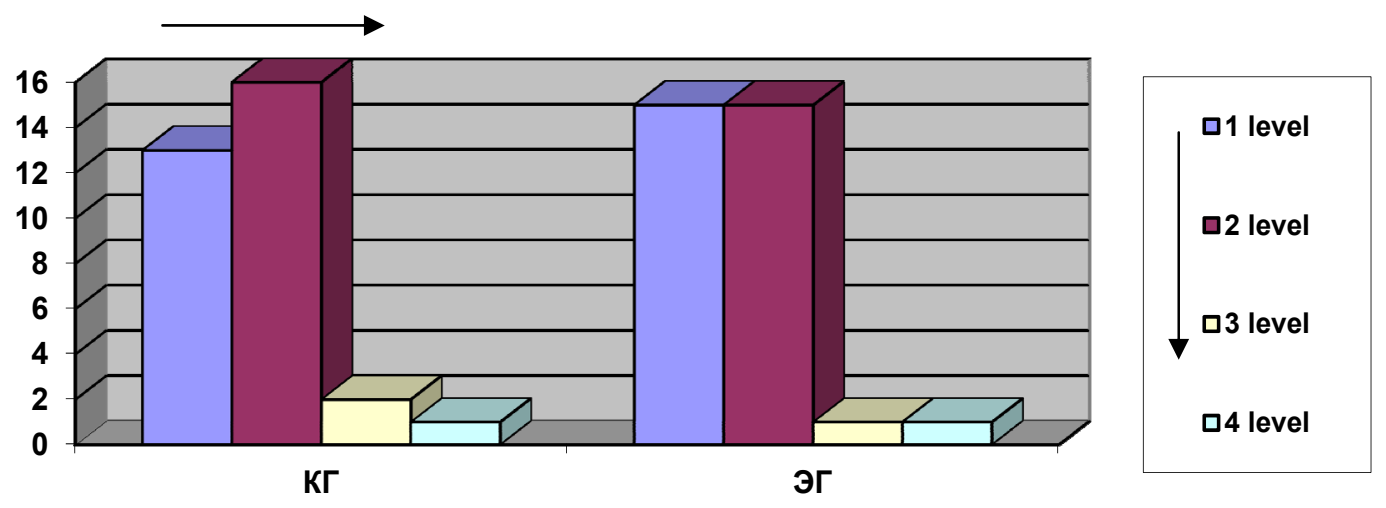

Figure 1. Ratio of knowledge in control group and experimental group prior to the experiment

The results of the experimental work show the effectiveness of the implementation of the regional component of general and special subjects determining professional motivation of college students' majoring in "Tourism".

\section{Discussions}

The background that contributed to the formation of college students professional motivation is the increasing role of tourism in the world, its impact on the economy and the regions, where Gzhel occupies a special position, specific characteristic of which is universally recognized cultural values of Arts and Crafts.

During the experiment the students of both groups were tested for the level of the students "motivational sphere" formation. The study showed a significant increase in the controlled parameters of the experimental group students compared to the students' results in the control group. The majority of the students in the experimental 
group reported a high level of professional motivation. The analysis of the process of formation of students' professional motivation in the experimental group will allow timely adjusting and improving the methods, tools and techniques used. The comparison of the professional motivation development within the experimental and control groups showed that the submitted model of the professionally-motivational education is more effective than the existing one which underestimates the regional component of professionally motivational students' education in the region of the developed folk arts and crafts.

\section{Conclusions}

The submitted syllabus of the regional component of the professionally motivating education of the students majoring in "tourism" comply with the following principles: compliance with the syllabus in the field of tourism and at all levels of design and common goals, disciplinary professional motivational training; the unity of its content and procedural parts; the structural unity of the syllabus of professionally motivating education at all levels of its formation; focus on the syllabus qualifying characteristics implementation; conformity of the professionally motivating learning content to the basic types of professional activity.

\section{Acknowledgments}

The authors thank all participants of this study for their kind cooperation.

\section{References}

Bugrimenko, A. G. (2006). Internal and external training motivation of students of pedagogical high school. Psychological Science and Education, 4, 34-37.

Dubovitskaya, D. (2003). On the problem of diagnosis of learning motivation. Questions psychology, 3, 73-78.

Gribenyuk, O. S., \& Gribenyuk, T. B. (1998). Introduction to the work of the teacher-researcher (p. 57). Kaliningrad.

Ilkevich, B. V. (2011). Problems and Prospects of Industrial Arts Education. Pedagogy, 6, 80-88.

Ilkevich, B. V., \& Ilkevich, K. B. (2013). Vocational and motivational art-industrial education (p. 204). Gzhel. GGHPI Press.

Ilkevich, B. V., \& Sukhodolova, E. P. (2011). Industrial Art Education in Gzhel. Higher education today, 3, 58-61.

Ilyin, E. P. (2004). Motivation and motives. St. Petersburg.

Lisitzina, T. B. (2007). Vocational and motivational training of students majoring in "Tourism" in the conditions of the region (p. 210). Thesis. Kazan.

Popov, V. A., \& Kondratyeva, O. Y. (1999). Changing the motivational value orientations of students. Sociological Studies, 6.

Shaidullina, A. R., Masalimova, A. R., Vlasova, V. K., Lisitzina, T. B., Korzhanova, A. A., \& Tzekhanovich, O. M. (2014). Education, science and manufacture integration models features in continuous professional education system. Life Science Journal, 11(8s), 478-485.

Verbitsky, A. A., \& Bakshaeva, N. A. (1998). Development motivation in learning context. Herald high school, $1(2), 47-50$.

Vishtak, O. V. (2003). Motivational preferences of applicants and students. Sociological Studies, 2.

\section{Copyrights}

Copyright for this article is retained by the author(s), with first publication rights granted to the journal.

This is an open-access article distributed under the terms and conditions of the Creative Commons Attribution license (http://creativecommons.org/licenses/by/3.0/). 